\title{
EVALUATION OF PITUITARY AND THYROID HORMONES IN PATIENTS WITH SUBARACHNOID HEMORRHAGE DUE TO RUPTURED INTRACRANIAL ANEURYSM
}

\author{
Paola Mangieri', Kunio Suzuki', Moema Ferreira², \\ Lucília Domingues ${ }^{3}$, Luiz Augusto Casulari4
}

\begin{abstract}
It is well known that the central nervous system (CNS) influences the pituitary hormone secretions and that diseases of CNS are frequently associated with an altered endocrine function. The aim of this study has been the evaluation of the serum concentrations of the pituitary and thyroid hormones in a series of patients with subarachnoid hemorrhage due to a ruptured cerebral aneurysm. Thirty-five patients ( 23 females and 12 males), aged $51.9 \pm 13.3$ years on the mean were admitted. They were evaluated to assess the clinical severity of the subarachnoid hemorrhage by Hunt \& Hess scale: nine patients were in the grade I, 14 in the grade II, and 12 in the grade III. Blood samples were obtained between 8:00 and 9:00 a.m. and serum hormones were measured by commercial kits (IRMA or MEIA methods). Cortisol serum levels (normal range $(N R)=5$ to $18 \mu \mathrm{g} / \mathrm{dL}$ ) were increased in all the patients (mean \pm standard deviation $=31.4 \pm 12.4 \mu \mathrm{g} / \mathrm{dL}$ ). Mean prolactin levels (NR $<20 \mathrm{ng} / \mathrm{mL}$ ) were $18.6 \pm 17.1 \mathrm{ng} / \mathrm{mL}$ and five patients $(14.2 \%)$ had levels higher than normal. FSH and LH levels were normal according to age and sex: men: $\mathrm{FSH}=4 \pm 2.9 \mathrm{mUl} / \mathrm{mL}(\mathrm{NR}=1$ to $10.5 \mathrm{mUl} / \mathrm{mL}) ; \mathrm{LH}=6.1 \pm 6.3 \mathrm{mUl} / \mathrm{mL}(\mathrm{NR}=2$ to $12 \mathrm{mUl} / \mathrm{mL}) ;$ premenopausa women: $\mathrm{FSH}=2.5 \pm 1.5 \mathrm{mUl} / \mathrm{mL}$ (NR = 2.4 to $9.3 \mathrm{mUl} / \mathrm{mL}) ; \mathrm{LH} 3.9 \pm 5.1 \mathrm{mUl} / \mathrm{mL}(\mathrm{NR}=2$ to $15 \mathrm{mUl} / \mathrm{mL}) ;$ post- menopausal women: $\mathrm{FSH}=$ $48.3 \pm 18.5 \mathrm{mUl} / \mathrm{mL}(\mathrm{NR}=31$ to $134 \mathrm{mUl} / \mathrm{mL}$ ); $\mathrm{LH}=29 \pm 13.8 \mathrm{mUl} / \mathrm{mL}(\mathrm{NR}=16$ to $64 \mathrm{mUl} / \mathrm{mL})$. Mean TSH levels were $3.9 \pm 5.2 \mu \mathrm{UI} / \mathrm{mL}$ (NR $=0.5$ to $4.7 \mu \mathrm{UI} / \mathrm{mL}$ ) and five patients $(14.2 \%)$ had levels higher than normal. Mean triiodothyronine levels (T3) were $66.4 \pm 18.7 \mathrm{ng} / \mathrm{dL}(\mathrm{NR}=45$ to $137 \mathrm{ng} / \mathrm{dL}$ ) and five patients (14.2\%) had levels lower than normal $(33.8 \pm 9 \mathrm{ng} / \mathrm{dL})$. Mean thyroxine levels (T4) $(\mathrm{NR}=4.5$ to $12.5 \mu \mathrm{g} / \mathrm{dL})$ were $7.4 \pm 1.7 \mu \mathrm{g} / \mathrm{dL}$ and two patients (5.6\%) had levels lower than normal. Thyroglobulin and microsomal antibodies were not detectable. Conclusions: In the first 24 hours following ictus, the hormonal changes may be due to the stress produced by the intracranial bleeding; thyroid hormone alterations suggest that patients with subarachnoid hemorrhage might have an euthyroid sick syndrome.
\end{abstract}

KEY WORDS: cerebral aneurysm, subarachnoid hemorrhage, pituitary, thyroid hormones, euthyroid sick syndrome.

\begin{abstract}
Avaliação dos hormônios hipofisários e tireoidianos em pacientes com hemorragia subaracnoidea devido a ruptura de aneurisma intracraniano

RESUMO - É bem conhecido que o sistema nervoso central (SNC) influencia as secreções dos hormônios hipofisários e que doenças do SNC são frequentemene associadas com função endócrina alterada. 0 objetivo deste estudo foi avaliar as concentrações séricas dos hormônios hipofisários e tireoidianos em uma série de pacientes acometidos de hemorragia subaracnóidea devida a ruptura de aneurisma cerebral. Foram avaliados 35 pacientes ( 23 mulheres e 12 homens), com média de idade de 51,9 $\pm 13,3$ anos. Foram avaliados para a severidade da doença pela escala de Hunt \& Hess: nove deles estavam no grau I, 14 no grau II e 12 no grau III. As amostras de sangue foram obtidas entre 8:00 e 9:00 horas e os hormônios foram medidos pelos métodos de IRMA ou de MEIA. Os níveis séricos de cortisol (valor normal (VN) 5 a $18 \mu \mathrm{g} / \mathrm{dl}$ ) estavam aumentados em todos os pacientes (média \pm desvio padrão $=31,4 \pm 12,4 \mu \mathrm{g} / \mathrm{dl}$ ). Os níveis de prolactina $(\mathrm{VN}<20 \mathrm{ng} / \mathrm{ml}$ ) foram de $18,6 \pm 17,1 \mathrm{ng} / \mathrm{ml}$ e cinco (14,2\%) tiveram níveis maiores do que o normal. Os níveis de FSH e $\mathrm{LH}$ foram

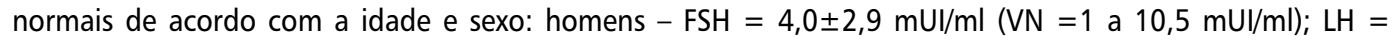
$6,1 \pm 6,3 \mathrm{mUl} / \mathrm{ml}(\mathrm{VN}=2$ a $12 \mathrm{mUl} / \mathrm{ml})$; mulheres - pré-menopausa: $\mathrm{FSH}=2,5 \pm 1,5 \mathrm{mUI} / \mathrm{ml}(\mathrm{VN}=2,4$ a 9,3 $\mathrm{mUl} / \mathrm{ml}) ; \mathrm{LH} 3,9 \pm 5,1 \mathrm{mUl} / \mathrm{ml}(\mathrm{VN}=2$ a $15 \mu \mathrm{Ul} / \mathrm{ml}) ;$ pós-menopausa: FSH $=48,3 \pm 18,5 \mathrm{mUl} / \mathrm{ml}$ (valor normal $=31$ a $134 \mathrm{mUl} / \mathrm{ml}) ; \mathrm{LH}=29 \pm 13,8 \mathrm{mUl} / \mathrm{ml}(\mathrm{VN}=16$ a $64 \mathrm{mUl} / \mathrm{ml})$. Os níveis de TSH foram 3,9 $\pm 5,2 \mu \mathrm{Ul} / \mathrm{ml}(\mathrm{VN}$ $=0,5$ a $4,7 \mu \mathrm{Ul} / \mathrm{ml})$ e cinco pacientes $(14,2 \%)$ tiveram níveis maiores do que o normal. Os níveis de triiodotironina
\end{abstract}

Study performed in the Neurosurgery Unit of the Hospital de Base do Distrito Federal (HBDF), Brasília DF, Brazil: ${ }^{1}$ Neurosurgery Unit HBDF; ${ }^{2}$ Laboratory of Hormone - HBDF; ${ }^{3}$ Brasilia University; ${ }^{4}$ Neurosurgery Unit - HBDF, Escola Superior em Ciências da Saúde - FEPECS.

Received 12 June 2002, received in final form 5 August 2002. Accepted 26 August 2002.

Luiz Augusto Casulari - Neurosurgery Unit - Hospital de Base do Distrito Federal; SMHS - Quadra 101 - $70335-900$ Brasília DF, Brazil. FAX:61-3254799. E-mail: roxomotta@ambr.com.br 
(T3) foram de $66,4 \pm 18,7 \mathrm{ng} / \mathrm{dl}(\mathrm{VN}=45$ a $137 \mathrm{ng} / \mathrm{dl})$ e cinco pacientes $(14,2 \%)$ tiveram níveis menores do que o normal $(33,8 \pm 9 \mathrm{ng} / \mathrm{dl})$. Os níveis de tiroxina (T4) $(\mathrm{VN}=4,5$ a $12,5 \mu \mathrm{g} / \mathrm{dl})$ foram de $7,4 \pm 1,7 \mu \mathrm{g} / \mathrm{dl}$ e dois pacientes $(5,6 \%)$ tiveram níveis menores do que o normal. Anticorpos antitireoglobulina e antimicrossomal não foram detectados. Conclusões: nas primeiras 24 horas seguindo o quadro ictal, as anormalidades observadas nas dosagens hormonais podem ser devidas ao estresse provocado pelo sangramento intracraniano; as alterações observadas nos hormônios tireoidianos sugerem que os pacientes com hemorragia subaracnoidea podem desenvolver a síndrome do doente eutireoideo.

PALAVRAS-CHAVE: aneurisma cerebral, hemorragia subaracnóidea, hipófise, hormônios tireóideos, síndrome do doente eutiróideo.

Spontaneous subarachnoid hemorrhage is a sudden blood extravasation in the subarachnoid space due to a blood vessel rupture, occurring more frequently at the level of a cerebral aneurysm ${ }^{1,2}$. The incidence of the disease is 10 cases for 100000 inhabitants, $56 \%$ in women, most frequently between the fifth and sixth decades ${ }^{1,2}$. Mortality before arriving at the hospital can reach $50 \%$ and is about $20 \%$ in the hospitalized patients ${ }^{2}$. Subarachnoid hemorrhage due to a ruptured intracranial aneurysm is associated with sudden headache, vomiting, loss of consciousness, stiff neck and paralysis of cranial nerves $^{1,2}$. The initial sudden headache is present in $91.3 \%$ of the patients and it is defined as unbearable and anguish, caused by alterations in the intracranial pressure. These signs and symptoms produce a distressing sensation of sudden death in the patient ${ }^{2}$.

It has been shown that acute and chronic stress situations produce alterations in the hormonal secretion. Stress produces its effects on the endocrine system by still poorly defined central pathways that stimulate the hypothalamus to release its secretagogues hormones at the level of the median eminen$\mathrm{ce}^{3,4}$. Major stresses, as important surgeries, traumas, hypovolemia, infections and intense pain increase hypothalamus-pituitary-adrenal axis activity producing corticotropin releasing hormone $(\mathrm{CRH})$, adrenocorticotropic hormone (ACTH), and cortisol hypersecretion. Morever, in these situations the day/night pattern of the ACTH - cortisol secretion and the negative feedback of the glucocorticoids appear to be disrupted ${ }^{5,6}$. The increased $\mathrm{CRH}$ and antidiuretic hormone $(A D H)$ secretion during stress can also be responsible of the decreased gonadotrophin releasing hormone $(\mathrm{GnRH})$ release and, consequently, of the pituitary gonadotrophin - FSH and LH- secretion. This effect can be mediated by opioid endogenous peptides that are also increased during stress ${ }^{7}$. Acute stress might also induce hyperprolactinemia and this can have some effect on the immune system and on the maintenance of the glycemic levels ${ }^{3}$. On the other hand, decreased TSH levels have been described during stress possibly due to increased somatostatin and interleukin 1 production ${ }^{4}$.
Neoplasic, inflammatory or vascular diseases invoIving the hypothalamus and/or the pituitary gland, as well as surgical and radiotherapic treatments of these structures have been reported to increase TSH serum levels ${ }^{8}$ and to produce a plurihormonal deficit of the pituitary hormones 9 .

Due to the important interactions between the central nervous system (CNS) and the endocrine system, particularly in stressfull situations as a spontaneous subarachnoid hemorrhage by ruptured cerebral aneurysm, we have analyzed the hormonal secretion profile of the major endocrine axes in the first 24 hours following an acute subarachnoid hemorrhage.

\section{METHOD}

Patients - Thirty-five subjects of both sexes were recruited from January of 1998 to July 1999 from patients hospitalized for spontaneous subarachnoid hemorrhage due to ruptured cerebral aneurysm in the Neurosurgery Unit of the "Hospital de Base do Distrito Federal". This is the principal public hospital with a neurosurgery unit of area of Brasília covering a user population of two millions of people.

The diagnosis of spontaneous subarachnoid hemorrhage was accomplished by anamnestic and physical findings and by brain computerized tomography. The presence of the aneurysm was determined by four-vessel conventional $x$-ray angiography (both carotids and both vertebrals), through femoral artery catheterism.

At admission to the hospital the patients were evaluated clinically and classified according to the Hunt \& Hess scale which is used exclusively in patients with spontaneous subarachnoid hemorrhage for clinical and prognostic assessement ${ }^{10}$. All the patients were followed until discharged from hospital. Before discharge they were also evaluated by the prognostic Glasgow scale ${ }^{11}$.

The inclusion criteria utilized were: spontaneous hemorrhage subarachnoid due to ruptured cerebral aneurysm (grade I to III in the Hunt \& Hess scale); absence of associated sistemic diseases, such as renal, heart, respiratory failure and diabetes mellitus. The exclusion criteria were: non aneurysmatic spontaneous subarachnoid hemorrhage; patients classified in grade IV and V of the Hunt \& Hess scale; patients previously using confounding drugs, as the replacement hormonal therapy of any type. 
Hormonal assays - Blood samples were collected between 8 and 9 AM, within 24 hours from ictus, centrifuged at $3000 \mathrm{rpm}$, for 10 minutes, and the serum stored at -20 C until assayed. Commercial "kits" were used: T3, T4, TSH and cortisol were assayed by immunofluorimetry (Autodelphia - São Paulo); FSH by microparticles enzymatic immunoassay (MEIA) (Abbott-São Paulo); LH and prolactin by an immunoluminescence assay (Elecys-São Paulo); antithyreoglobulin and antimicrossomal antibodies by indirect hemoagglutination (Bayer - São Paulo).

Statistical analysis - Data were analyzed by the analysis of the variance (ANOVA) utilizing the Dunnett test for comparisons; the level of significance was fixed at $p<0.05$. The results are presented as mean \pm standard deviation $(M \pm S D)$.

This study was approved by the Committee of Ethics in Research of the "Secretaria de Saude do Distrito Federal". Patients or their legal representatives signed the informed consent for participation in the study.

\section{RESULTS}

Thirty-five patients entered the study: 23 females and 12 males, aged $51.9 \pm 13.3$ years on average. The difference between the age of females (52.5 \pm 14.8 years) and of males ( $51 \pm 3.3$ years) was not statistically significant. The location of the aneurysms is shown in Table 1. Nine patients were classified in grade I of the Hunt \& Hess scale (asymptomatic or with minimal to discrete headache), fourteen in grade II (moderate to severe headache, stiff neck and absence of focal neurological signs, except cranial nerves paralysis) and twelve in grade III (sleepiness, mental confusion and discreet focal neurological deficits).
As shown in Table 2, cortisol levels were increased in all the patients and no difference was observed between the mean values present in the different sexes. Prolactin levels were significantly lower in men than in women $(p<0.05)$ (Table 2$)$. Five patients $(14.2 \%)$ had prolactin levels above the normal range. FSH and $\mathrm{LH}$ levels were normal for age and sex. As expected, the post-menopausal women showed significantly higher FSH and LH levels than the premenopausal ones (Table 2).

TSH, T3, and T4 levels were similar in men and in women (Table 2 ). Five patients (14.2\%) had TSH levels higher than normal. T3 levels were lower than normal in five patients (14.2\%), with a mean value of $33.8 \pm 9$ $\mathrm{ng} / \mathrm{dL}$. The levels of T4 were low in two patients (5.6\%). Antithyreoglobulin and antimicrosomal antibodies were not detected in any patient.

Table 1. Distribution of the cerebral aneurysms in 35 patients with subarachnoid hemorrhage due to spontaneous rupture of a cerebral aneurysm.

\begin{tabular}{lcc}
\hline Artery & cases $(\mathrm{n})$ & $\%$ \\
\hline Anterior communicans & 12 & 34.2 \\
Posterior communicans & 6 & 17.1 \\
Media cerebri & 5 & 14.2 \\
Multiple aneurysms & 5 & 14.2 \\
Other locations & 7 & 20 \\
\hline
\end{tabular}

Table 2. Hormone levels in 35 patients with subarachnoid hemorrhage due to ruptured cerebral aneurysm $(M \pm S D)$.

\begin{tabular}{lccc}
\hline Hormones (normal range) & Female $(\mathrm{n}=23)$ & Male $(\mathrm{n}=12)$ & Total $(\mathrm{n}=35)$ \\
\hline Cortisol $(5$ to $18 \mu \mathrm{g} / \mathrm{dL})$ & $25.5 \pm 14$ & $28.8 \pm 11.4$ & $31.4 \pm 12.4$ \\
Prolactin $(<20 \mathrm{ng} / \mathrm{mL})$ & $19.3 \pm 17.9 *$ & $11.9 \pm 0.2$ & $18.6 \pm 17.1$ \\
FSH $(1$ to $10.5 \mathrm{mUl} / \mathrm{mL})$ & - & $4 \pm 2.9$ & - \\
Pre-menopause $(2.4$ to 9.3$)$ & $2.5 \pm 1.5$ & - & - \\
Post-menopause $(31$ to 134$)$ & $48 \pm 18.5 * *$ & - & - \\
LH $(2$ to $12 \mathrm{mUl} / \mathrm{mL})$ & - & $6.1 \pm 6.3$ & - \\
Pre-menopause $(2 \mathrm{at} 15)$ & $3.9 \pm 5.1$ & - & - \\
Post-menopause $(16$ to 64$)$ & $29(13,8 * *$ & - & - \\
TSH $(0.5$ to $4.7 \mu \mathrm{U} / \mathrm{mL})$ & $3.7 \pm 4.8$ & $2.6 \pm 1.7$ & $3.9 \pm 5.2$ \\
T3 $(45$ to $137 \mathrm{ng} / \mathrm{dL})$ & $66.9 \pm 19.2$ & $66.6 \pm 18.7$ & $66.4 \pm 18.7$ \\
T4 $(4.5$ to $12 \mu \mathrm{g} / \mathrm{dL})$ & $7.1 \pm 1.8$ & $7.8 \pm 1.6$ & $7.4 \pm 1.7$ \\
\hline * $\mathrm{p}<0.05 \mathrm{Vs} \mathrm{male} * * \mathrm{p}<0.05 \mathrm{Vs}$ pre - menopause & &
\end{tabular}


Evolution: All the patients were submitted to surgical treatment. Most (70\%) of the patients were finally classified in grade 4 and 5 of the prognostic Glasgow scale. Two deaths occurred: one for rupture of the aneurysm during surgery and the other for lung infection.

\section{DISCUSSION}

The increase of the cortisol in all our patients probably reflects the high level of stress produced by the subarachnoid hemorrhage due to the ruptured aneurysm; it is probably produced by a combination of psychological stress and pain, with the possibile involvement of the hypotension and hypovolemia. Increased levels of cortisol has been described in other types of intense stress, such as severe trauma, burns, important surgery, hypotension and serious systemic diseases ${ }^{12,13}$. The intense stress exerts its effects by not well defined central pathways which stimule the $\mathrm{CRH}$ neurons located in the hypothalamus to secrete $\mathrm{CRH}$ in the pituitary portal system. ACTH is then hypersecreted by the pituitary gland, stimulating in its turn cortisol liberation by the adrenal glands ${ }^{14}$. The intense stress disrupts the day/night pattern of the ACTH and cortisol secretions, and abolishes the negative feedback of cortisol at the hypothalamic-pituitary leve ${ }^{5,6,15}$.

Antidiuretic hormone (ADH) and norepinephrine are other ACTH secretagogues that acts sinergistically with $\mathrm{CRH}$ in the regulation of the response to stress ${ }^{14}$. On the other hand, endorphinergic fibers are part of the stress pathways involved in the cortisol and ACTH responses, as it has been shown to occur in major surgeries ${ }^{16}$.

The increase of the cortisol during the stress certainly represent a vital mechanism of defense of the organism in the maintenance of the homeostasis in these situations. The glucocorticoids can rapidly induce alterations of the excitability of the neuronal membranes ${ }^{17}$. They may also affect the cerebrovascular permeability and the choroidal transport of water and electrolytes, being important in the regulation of the synthesis of liquor and in the brain volume homeostasis ${ }^{4}$. Complex interactions between the hypothalamus-pituitary-adrenal axis and the immune system can also have a fundamental physiological importance in the stress reponse ${ }^{18}$. Glucocorticoids produce a multistep inhibition of the immune system protecting the organism from the consequences of excessive inflammatory reactions $s^{15,18,19}$.

Prolactin levels were significantly higher in the women than in the men. This fact is not surprising since estrogen levels are higher in women and represent a strong stimulus for prolactin secretion ${ }^{20}$. Estrogens stimulate mRNA production and the prolactin synthesis in the pituitary gland and also promote the mitotic activity of lactotrophs. It has been reported that acute stress increases prolactin levels ${ }^{21}$. However, we observed that only a minority of our patients had high prolactin levels, but this can be due to a too late withdrawal of the blood sample after the acute ictal episode (within 24 hours). As a matter of fact it is known that prolactin, after an acute stress, reaches a peak which exceedes two to three times its basal levels, but it rapidly goes back to the normal level within one hour ${ }^{21}$. Moreover, the prolactin increase might have been limited by the concomitant increase of the cortisol observed in all our patients. It has been described that the prolactin secretion provoked by stress in adrenalectomized mice results in a longer lasting increase in prolactin ${ }^{22,23}$.

Endogenous opioid peptides are probabily involved in the mechanism of stress induced hyperprolactinemia, since it has been shown that the naloxone, an opioid antagonist, blocks to a large extent prolactin levels following surgical stress ${ }^{24}$. The physiological role of prolactin hypersecretion during the acute stress is not clear; some beneficial effects on the immune system ${ }^{3,25}$ and on the maintenance of the glycemic levels ${ }^{3}$ have been proposed.

We did not record in our patients alterations of FSH and LH levels, both in men and in women. This observation is to a certain extent in disagreement with the data of the literature. It has been reported that stress frequently causes menstrual alterations, mainly amenorrhoea, with low or normal FSH and LH levels, associated with low or normal estrogen secretion suggesting a possible effect at the hypothalamic level ${ }^{26}$. Moreover, the development of hypogonadotrophic hypogonadism is common during acute diseases ${ }^{27}$. However studies in subjects hospitalized for cranial traumatisms, acute myocardium infarction and surgery have shown that the most significant decrease of FSH occurs two days after the beginning of the stress and that the reduced $\mathrm{LH}$ secretion only after four days ${ }^{28}$. Since the blood samples of in our study were never obtained later than 24 hours after ictus it is possible that is this short time interval explains the apparent discrepancy. Moreover, the use of drugs, such as dopamine, glucocorticoids and opioids, in acutely sick patients, can also contribute to the decrease of $\mathrm{LH}$ and testosterone ${ }^{29}$ secretion, and these drugs were not used in our patients. Finally it has been shown that the 
alterations in FSH and testosterone levels, but not of $\mathrm{LH}$, are correlated with the severity of the disease measured by the APACHE score (Acute Physiology and Chronic Health Evaluation) ${ }^{29}$ and our patients, being all included in grade I to III of the Hunt $\&$ Hess classification, were not so seriously health compromised.

The great majority of our patients did not presented alterations in TSH, T4, and T3 secretions; only five patients showed high TSH levels, other five decrease T3 and two low T4. Antithyrod antibodies were never present. Even if it is not possible to completely exclude the possibility of an associated thyroid disease in our patients, the absence of antibodies against thyroid might be considered as indicative of the absence of primary hypothyroidism ${ }^{30}$. Increased levels of TSH have been described in patients with serious sistemic diseases ${ }^{31,32}$, with hypothalamic and pituitary tumors $8,9,30,33$, following surgery or cerebral radiotherapy ${ }^{8}$ often producing diagnostic confusion with primary hypothyroidism ${ }^{8}$.

The observation that the great majority of our patients have normal TSH levels and none shows suppressed levels of the hormone is somehow surprising, since it has been reported that the stress produces a decreased TSH secretion, effect mediated by the somatostatin and interleukin $1^{4,34}$. Morever, cortisol levels were increased in all the patients and this hormone has a known inhibitory effect on TSH secretion. Pharmacological doses of glucocorticoid reduce TSH secretion in normal and hypothyroid patients, blunt the TSH response to TRH and abolish the night increase of $\mathrm{TSH}^{34-36}$. Hydrocortisone infusions, simulating the levels of cortisol present during moderate stress, suppress TSH secretion ${ }^{35}$. Finally, the levels of TSH are more elevated in patients with adrenal insufficiency and they decrease during the physiologic replacement therapy with glucocorticoids ${ }^{36}$. Even if we have not observed a decreased TSH secretion, this does not exclude the possibility that the high cortisol levels have affected TSH secretion in our patient with subarachnoid hemorrhage. This because the low T3 and T4 levels observed in some patient was not accompanied by the normal compensatory increase of the TSH levels. This observation suggests that some degree of inhibition of the TSH secretion could have been exerted by the high cortisol levels in these patients.

The presence of low T3 or low T4 levels, with a normal TSH concentration (and absence of antithyroid antibodies) in the first hours following ictus, suggests that a small group of patients with subarachnoid hemorrhage might have an euthyroid sick syndrome ${ }^{37,38}$. This syndrome is characterized by a decreased serum T3, increased reverse T3 levels, associated or not to normal TSH and T4 levels ${ }^{37,38}$. The low T3 serum concentrations are due to a decreased conversion of T4 to T3 in the peripheral tissues, including liver and kidneys, that are the major responsibles of circulating $T 3^{37,38}$. The inhibition of the iodotironinedeiodinase type I, that metabolizes T4 to T3, can be due to the high cortisol levels found in our patients with subarachnoid hemorrhage, since pharmacological doses glucocorticoid block the conversion of T4 to T3, increasing the conversion of T4 to reverse $T 3^{34,39}$. It is therefore possible that the alterations observed in our patients and that is characteristic of euthyroid sick syndrome may be due to the high cortisol levels.

In conclusion, the hormonal abnormalities observed in the first 24 hours following ictus in patients with subarachnoid hemorrhage can be produced by the stressful stimulus provoked by the intracranianial bleeding. The high cortisol levels observed in all the patients can have an important role in producing these hormonal alterations. It is possible that some patient develops an euthyroid sick syndrome.

Acknowledgements - We are indebted to Professor Fabio Celotti for his advice and criticism. We gratefully apreciate the technical assistance of Luiz Gustavo Domingues Casulari da Motta.

\section{REFERENCES}

1. Mello PA, Hermes M Jr, Suzuki K, et al. Doença vascular hemorrágica. Rev Bras Neurol 1992;28:143-145.

2. Pereira RSS, Casulari LA, Leal MB Filho, et al. Aneurisma da artéria carótida interna: estudo de 510 pacientes. Bras Med 2001;38:20-26.

3. Molitch ME. Prolactin. In Melmed S (ed) The pituitary. Cambridge: Blackwell 1995;136-186.

4. Reichlin S. Neuroendocrinology. In William JDJ, Foster DW (eds) Williams textbook of endocrinology. 8.Ed. Phyladelphia: Saunders, 1992; 135-220.

5. Reincke M, Allolio B, Wurth G, Winkelmann W. The hypothalamicpituitary-adrenal axis in critically ill patients: response to CRH and dexamethasone. J Clin Endocrinol Metab 1993;77:151-156.

6. Drucker D, McLaughlin J. Adrenocortical dysfunction in acute medical illness. Crit Care Med 1986;14:789-791.

7. Gundoff PR, Ferin M. Endogenous opioid peptides modulate the effect of CRH on gonadotropin release in the primate. Endocrinology 1987;121:837-42.

8. Motta LACR, Martins JWG, Motta LDC, Moraes AA, Farage M Filho. Aumento sérico do hormonio estimulante da tireóide (TSH) em portadores de tumores selares ou paraselares, antes ou após tratamento com cirurgia e/ou radioterapia. Ars Curandi 1997;30:12-22.

9. Motta LACR, Martinelli C, Motta LDC, Abrahão AL, Farage M Filho, Gagliardi ART. Efeitos tardios na função hipotálamo-hipófise após tratamento de tumores paraselares. Arq Neuropsiquiatr 1991;49:299-306.

10. Hunt WE, Hess RM. Surgical risk as related to time of intervention in the repair of intracranial aneurysms. J Neurosurg 1968:28:14-20.

11. Jennett $B$, Bond M. Assessment of outcome after severe brain damage: a practical scale. Lancet 1975;1:480-484.

12. Orth DN, Kovacs WJ, Debold R. The adrenal cortex. In Wilson JD, Foster DW 8.Ed. Williams textbook of endocrinology; Phyladelphia: Saunders, 1992:489-619. 
13. Vaughan GM, Becker RA, Allen JP, Goodwin CW, Pruitt BA, Mason AD. Cortisol and corticotropin in burned patients. J Trauma 1982;22:263-272.

14. Moore-Ede MC, Czeisler CA, Richardson GS. Circadian timekeeping in health and disease: Part 1. N Engl J Med 1983;309:469-476.

15. Chrousos GP. The hypothalamic-pituitary-adrenal axis and immunemediated inflammation. N Engl J Med 1995;332:1351-1362.

16. Raff H, Norton AJ, Flemma RJ, Findling JW. Inhibition of the adrenocorticotropin response to surgery in human: interaction between dexamethasone and fentanyl. J Clin Endocrinol Metab 1987;65:295-298.

17. Hua SY, Chen YZ. Membrane receptor-mediated electrophysiological effects of glucocorticoid on mammalian neurons. Endocrinology 1989;124:687-691.

18. Munck A, Guyre PM, Holdbrook NJ. Physiological functions of glucocorticoids in stress and their relation to pharmacological actions. Endocr Rev 1984;5:25-44.

19. Vamvakopoulos NC, Chrousos GP. Hormonal regulation of human corticotropin-releasing hormone gene expression: implications for the stress response and immune/inflammatory reaction. Endocr Rev 1994;15:409-420.

20. Motta LDC, Gandulfo V, Simões P, Zaconeta A, Silva NC, Motta LACR. Hiperprolactinemia: avaliação etiológica, clínica e laboratorial. Rev Bras Ginec Obstetr 1997;19:573-586.

21. Noel GL, Suh HK, Stone SJG, Frantz AE. Human prolactin and growth hormone release during surgery and other conditions of stress. J Clin Endocrinol Metab 1972;35:840-851.

22. Harms PG, Langlier P, McCann SM. Modification of stress - induced prolactin release by dexamethasone on adrenalectomy. Endocrinology 1975;1996: 475-478.

23. Subramanian MG, Gala RR. The influency of adrenalectomy and of corticosterone administration on the ether-induced increase in plasma prolactin in ovariectomized estrogen-treated rats. Proc Soc Exp Biol Med 1978;157:415-417.

24. Corenblum B, Taylor PJ. Mechanisms of control of prolactin release in response to apprehension stress and anesthesia-surgery success. Fertil Steril 1981;36:712-715.

25. Gala RR. The physiology and mechanisms of the stress induced changes in prolactin secretion in the rat. Life Sci 1990;46:1407-1420.
26. Loriaux L, Nieman L. Stress and reproduction; the role of cortisol. In Yen SSC, Worth WW (eds). Neuroendocrine regulation of reproduction. Nowell: Serono Symposia, 1990:307-312.

27. Vogel AV, Peake GT, Rada RT. Pituitary - testicular axis dysfunction in burned men. J Clin Endocrinol Metab 1985;60:658-665.

28. Wolff PD, Hamil RW, McDonald JV, Lee LA, Kelly M. Transient hypogonadotropic hypogonadism caused by critical illness. J Clin Endocrinol Metab 1985;60:444-454.

29. Spratt DI, Cox P, Orav J, Moloney J, Bigos T . Reproductive axis suppression in acute illness is related to disease severity. J Clin Endocrinol Metab 1993;76:1548-1554.

30. Faglia G, Bitensky L, Pinchera A, et al. Thyrotropin secretion in patients with central hypothyroidism: evidence for reduced biological activity of imunoreactive thyrotropin. J Clin Endocrinol Metab 1979;48:989-998.

31. Brent GA, Hershman JM, Braunstein GD. Patients with severe nonthyroidal illness and serum thyrotropin concentrations in the hypothyroid range. Am J Med 1986;81: 463-466.

32. Cavalieri RR. The effects of nonthyroid disease and drugs on thyroid function tests. Med Clin N Am 1991;75: 27-39.

33. Motta LACR, Garcia OV Filho, Horta MP, Lima BO, Pratesi R, Farage M Filho. Síndrome de Russel: tumor diencefálico em uma criança. Arq Neuropsiquiatr 1990;48:107-112.

34. LarsenPR, IngbarSH. The thyroid gland. InWilsonJD, FosterDW (ed.)Williams textbook of endocrinology. 8.Ed. Philadelphia: Saunders 1992: 357-487.

35. Samuels MH, Lutter M, Henry P, Ridgway EC. Effects of hydrocortisone on pulsatile pituitary glycoprotein secretion. J Clin Endocrinol Metab 1994;78:211-215.

36. Sarapura VP, Samuels MH, Ridgway EC. Thyroid-stimulating hormone. In Melmed S (ed). The pituitary. Cambridge: Blackwell, 1995;187-229.

37. Wastofsky L, Burman KD. Alterations in thyroid function in patients with systemic illness: the "euthyroid sick syndrome." Endocr Rev 1982;3:164-217.

38. Peters JR, Foord SM, Dieguez C, Scanlon MF. TSH neuroregulation and alterations in disease states. Clin Endocrinol Metab 1983;12:669-695.

39. Williams OF, Chopra IJ, Orgiazzi J, Solomon DH. Acute effect of corticosteroids on thyroid activity in Grave's disease. J Clin Endocrinol Metab 1975;41:354-361. 